\title{
Effect of Batissa violacea celebensis Martens, 1897, Extract on $\beta$-Catenin Gene in Mice (Mus musculus) Induced by Azoxymethane and Dextran Sulfate Sodium using Polymerase Chain Reaction- restriction Fragment Length Polymorphism Method
}

\author{
Sri Anggarini Rasyid*(D), Sanatang Sanatang (iD, Satriani Syarif(D), Sugireng Sugireng (D), Titi Purnama (i), Suwarny Suwarny (D), \\ Yayan Kurniansyah Saputra \\ D-IV Program of Medical Laboratory Technology, Faculty of Science and Technology, Universitas Mandala Waluya, Kendari, \\ Southeast Sulawesi, Indonesia
}

Edited by: Slavica Hristomanova-Mitkovska Citation: Rasyid SA, Sanatang S, Syarif S, Sugireng S, Purnama T, Suwarny S, Saputra YK. Effect of Batiss violacea celebensis Martens, 1897, Extract on $\beta$-Catenin Gene in Mice (Mus musculus) Induced by Azoxymethane and Dextran Sulfate Sodium using Polymerase Chain Reaction-restriction Fragment Length Polymorphism Method. Open-Access Maced J Med Sci. 2021 Sep 24; 9(A):964-970. https://doi.org/10.3889/oamjms.2021.6987 Keywords: $\beta$-catenin gene; Colorectal cancer; Mutation ( Cong *Correspondence: Sri Anggarini Rasyid, D-IV Program of Medical Laboratory Technology, Faculty of Science and Technology, Universitas Mandala Waluya, Kendari, Southeast Sulawesi, Indonesia. E-mail: anggarini.09@gmail.com Received: 03-Aug-202 Revised: 20-Aug-202 Accepted: $14-\mathrm{Sep}-202$ Copyright: ๑ 2021 Sri Anggarini Rasyid, Sanatang Sanatang, Satriani Syarif, Sugireng Sugireng, Tr Funding: This research did not receive any financia

support Competing Interest: The authors have declared that no competing interest exists

Open Access: This is an open-access article distribute under the terms of the Creative Commons AttributionNonCommercial 4.0 International License (CC BY-NC 4.0)

\section{Introduction}

$\beta$-catenin gene plays an important role in the cell adhesion system mediated by cadherins and in signal transduction at the Wingless (Wnt) signaling pathway binding T-cell factor in the nucleus and regulates gene transcription related to cell development and differentiation. The regulation derivative of the $\beta$-catenin gene binds adenomatous polyposis coli (APC) protein and phosphorylation by glycogen synthase kinase-3 beta (GSK3ß)/serine-threonine kinase causing the $\beta$-catenin gene stabilization in the cytoplasm and can induce the activation of the constitutive transcription of Tcf derivation from DNA-binding proteins. $\beta$-catenin gene mutation has been found in the $50 \%$ of human colon tumors in APC. This indicates that the activation of $\beta$-transcriptional pathways mediated by catenin/Tcf is caused by the mutation of the APC or $\beta$-catenin gene that is strongly important for colorectal neoplasia [1].

$\beta$-catenin-CTNNB1 gene is the central component of adherens junctions (AJs) having the capability to bind E-cadherin in the epithelial cells and stabilize the cytoskeleton in preventing abnormal cell growth. AJ is crucial in the growth regulation and adhesion between epithelial cells. At the cell level, $\beta$-catenin gene mutation can transmit the signal that causes cell lyses, especially during the growth plate of epithelial cells [2].

The factors involved in colorectal cancer development can be categorized into three groups, namely, genetic factor, epigenetic factor, and environmental factor. These factors result in the variation of growth pathways and cell proliferation. The genetic factor is one of the most significant factors where the gene changes and signaling pathways cause 
a failure of normal gene functions. The cell process of the $\beta$-catenin gene involves many genes that interact with each other and regulates cellular activities, such as cell proliferation, transformation, cell growth, and cell invasion [3].

Azoxymethane (AOM) is a pro-carcinogen that is structurally similar to cycasin, a compound that can induce colorectal tumors. AOM is used in biological research and is strongly effective for inducing colorectal carcinoma or cancer that grows from the skin tissues or the tissues structuring the organ walls. In the carcinogenesis of the colon in mice induced by AOM, $\mathrm{K}$-ras gene mutations often happen as colorectal tumors happened in humans, yet, in APC, gene changes are rarely observed [3].

The bivalve extract has steroid compounds that are assumed to increase stamina (aphrodisiacs) and anti-inflammation. The component of triterpenoids detected in the crude extract of bivalves is believed to have antitumor activities. Natural triterpenoids have antitumor activities since they can inhibit the performance of type II topoisomerase by binding the active site of the enzyme that will bind DNA and cleaving it, thus, the enzyme is locked and it cannot bind DNA [4]. Pokea extract can be collected by the extraction process. Extraction is the process of separating a substance from a mixture using a suitable solvent. The extraction process is stopped when the balance between the concentration of compounds in the solvent and the concentration in the plant cells or animal cells is achieved. The solvents used in this study were non-polar $\mathrm{N}$-hexane, ethanol $(\mathrm{EtOH})$ as a polar solvent, and semi-polar ethyl acetate [5].

Based on the statement above, it is important to conduct a study on $\beta$-catenin gene mutation in mice that have been given pokea (B. violacea celebensisMartens, 1897) extract available in Southeast Sulawesi. The researcher was interested in conducting a study entitled "Effect of Pokea (Batissa violacea Celebensis Martens 1897) Extract on $\beta$-Catenin Gene Mutation in Mice Induced by AOM and Dextran Sulfate Sodium (DSS)."

\section{Methods}

\section{Maceration process and filtering the B. violacea celebensis Martens, 1897, extract (Rasyid et al., 2017) [5]}

Pure $\mathrm{EtOH}$ solvent used $2 \mathrm{~L}$ of distillation results. Soaking was done with $2 \mathrm{~L}$ of pure $\mathrm{EtOH}$, after that, it was allowed to stand for $3 \times 24 \mathrm{~h}$. For $1 \times 24 \mathrm{~h}$, the concentration process is carried out by evaporation, then the filtrate is filtered (Rasyid et al., 2017) [5].

\section{Evaporation stage}

Two liters of macerates from the filtering process are evaporated. The evaporation process was conducted using a rotary vacuum evaporator. This process was conducted until the thick extract was formed. Then, it was moved and scaled (the extraction product of $1 \mathrm{~kg}$ pokea clam produced $6 \mathrm{~g}$ of extract).

\section{Fractionation process of EtOH extract} using ethyl acetate and $n$-hexane solvents [6]

a. The ethyl acetate fraction was obtained by taking $24 \mathrm{~g}$ of EtOH extract, dissolved again with $\mathrm{EtOH}$ until dissolved. Then, the extract filtrate was put into a separating funnel and $200 \mathrm{ml}$ of ethyl acetate was added to form a layer. Added $50 \mathrm{ml}$ of distilled water. Then, the fractionation process is carried out with the solvent indicator becoming clear. A filtrate was formed with an aqueous phase of $\mathrm{EtOH}$ and an organic filtrate of ethyl acetate. The ethyl acetate filtrate was concentrated to become ethyl acetate extract

b. The n-hexane fraction was obtained by taking $24 \mathrm{~g}$ of EtOH extract and diluted with EtOH until dissolved. The extract filtrate was put into a separating funnel and $300 \mathrm{ml}$ of $\mathrm{N}$-hexane was added to form a layer. Added $60 \mathrm{ml}$ of distilled water. Then, the fractionation process is carried out with the solvent indicator becoming clear. A filtrate is formed with the water phase of $\mathrm{EtOH}$ and organic $\mathrm{N}$-hexane filtrate.

\section{Preparation of experimental mice}

This study had obtained ethical approval from the ethical committee of the Faculty of Medicine, Universitas Hasanuddin, with the following registration number: UH20110627. The colon sample was taken after injecting AOM/DSS as a treatment and ensuring that the mice experience dysplasia, except for the negative control, the AOM/DSS treatment was not given [7]. Next, EtOH extract, ethyl acetate fraction, and $n$-hexane fraction were given with a dosage of $0.25 \mathrm{mg} / \mathrm{ml}$ to each mouse group for 14 days.

\section{DNA extraction}

\section{Protein removal}

Put $15 \mathrm{mg}$ of fresh animal tissue (colon) into a $1.5 \mathrm{ml}$ microcentrifugation tube. Added 25 I of GST buffer and $20 \mathrm{I}$ of proteinase $\mathrm{K}$. Divortex, then incubated at $60^{\circ} \mathrm{C}$ until the sample looks clear.

\section{Cell lysis}

The insoluble material was centrifuged for 2 min at $14-16,000 \times g$, the supernatant was transferred 
to a new $1.5 \mathrm{ml}$ microcentrifuge tube. Added $200 \mathrm{~L}$ of GSB buffer and vortexed for $10 \mathrm{~s}$.

\section{DNA binding}

Added 200 I of absolute $\mathrm{EtOH}$ to the sample lysate and shaken vigorously for $10 \mathrm{~s}$. The GS column was placed in a $2 \mathrm{ml}$ collection tube, then centrifuged at $14-16,000 \times \mathrm{g} 1 \mathrm{~min}$. Discard the $2 \mathrm{ml}$ collection tube containing the filtrate and transfer the GS column to a new $2 \mathrm{ml}$ collection tube.

\section{Washing}

Add $400 \mathrm{~L}$ of buffer $\mathrm{W} 1$ to the GS column tube at $14-16.000 \times \mathrm{g}$ for $30 \mathrm{~s}$ and discard the filtrate. Place the GS column back into the $2 \mathrm{ml}$ collection tube. Add $600 \mathrm{~L}$ of wash buffer (make sure absolute $\mathrm{EtOH}$ is added) to the GS column at a centrifuge of 14-16.000 $\times \mathrm{g} 30 \mathrm{~s}$ then discard the filtrate. Place the GS column back into the $2 \mathrm{ml}$ collection tube. Centrifuge again for $3 \mathrm{~min}$ at $14-16,000 \times \mathrm{g}$. The dry GS column was transferred to a $1.5 \mathrm{ml}$ microcentrifuge tube. Add $100 \mathrm{~L}$ of preheated elution buffer. Let stand for $3 \mathrm{~min}$, then centrifuge at $14-16,000 \times \mathrm{g} 30 \mathrm{~s}$.

\section{Polymerase chain reaction (PCR) process}

Added DNA template $200 \mathrm{mg}$. Each primer was taken $1 \mathrm{~L}$ each. Then, the MyTaq HS Red Mix reagent kit, $2 \times$ as much as $25 \mathrm{~L}$ was added. Water was added until the sample volume became $50 \mu \mathrm{l}$, then homogenized. The amplification process was carried out in a PCR machine with pre-denatured conditions of $95^{\circ} \mathrm{C}$ for $1 \mathrm{~min}$ and followed by denaturation of $95^{\circ} \mathrm{C}$ for $15 \mathrm{~s}$, annealing at $57^{\circ} \mathrm{C}$, and extension at $72^{\circ} \mathrm{C}$ for $10 \mathrm{~s}$.

\section{Restriction fragment length polymorphism (RFLP) analysis (restriction digestion)}

The results of PCR amplification were digested using the Hinf1 enzyme which consisted of mixing $10 \mu \mathrm{L}$ PCR reaction ( 0.1-0.5 g DNA), $18 \mu \mathrm{L}$ nuclease-free water, $10 \times$ buffer $\mathrm{R} 2 \mu \mathrm{L}$, and 1-2 L Hinfl, then stir gently and turn it down for a few seconds. It was incubated at $37^{\circ} \mathrm{C}$ for $1 \mathrm{~h}$ and the incubation temperature was raised to $65^{\circ} \mathrm{C}$ for $20 \mathrm{~min}$.

\section{Electrophoresis process}

$P C R$ results in the electrophoresis process

The tray position was adjusted and 1XTAE buffer $\mathrm{pH} 8.0500 \mathrm{ml}$ was poured into the electrophoresis tank. Then, $5 \mathrm{~L}$ of the DNA sample was mixed and inserted into the agarose gel well, the current-voltage and running time were set at $100 \mathrm{~V}$, $35 \mathrm{~A}$, and $30 \mathrm{~min}$.

\section{Analysis of Hinf1 digestion products using electrophoresis}

To know the result of DNA amplification, electrophoresis was applied to the Hinfl digestion products in agarose gel of $2-3 \%$. Around $2-3 \%$ was made by dissolving $2-3 \mathrm{~g}$ of agarose in $100 \mathrm{ml}$ buffer $1 \times T A E$ with $\mathrm{pH} 8$ and was heated until boiled. After being homogenized and the agar was cool (approximately $\left.60^{\circ} \mathrm{C}\right)$, DNA staining was added $(1 \mu \mathrm{L} / 30 \mathrm{ml})$. The agarose solution was poured into an agarose gel container, and the electrophoresis comb was installed at one of the tips of the agarose gel container. After the gel was solid, the comb was removed carefully.

The container position was set and $500 \mathrm{~mL}$ of buffer TAE $1 \times \mathrm{pH} 8.0$ was poured into the electrophoresis tank. Furthermore, $10 \mu \mathrm{L}$ of DNA sample mixture was poured into the agarose gel well; the voltage, electric current, and running time were set at $100 \mathrm{~V}, 1 \mathrm{~A}$, and $90 \mathrm{~min}$, consecutively. After the electrophoresis finished, the gel was placed in the ultraviolet (UV) transilluminator; then, the visualized DNA bands were observed.

\section{DNA visualization of PCR and HinfI digestion products}

DNA visualization of PCR results and Hinfl digestion had the same procedure, namely, placing the gel into the UV transilluminator device by removing the gel from the mold. Then, the gel is exposed to UV light. The image of the gel formed under UV light is then documented. The DNA bound to the red gel will be exposed under UV light.

\section{DNA sequences analysis (PT genetica sains)}

DNA bands of the Beta-catenin gene obtained from the sample the results of electrophoresis carried out DNA sequencing through PT. Genetics Science Indonesia to see changes in the sequence of the Betacatenin gene. DNA sequencing, the PCR method is used as the basis. The DNA for which the ACGT base sequence will be determined is used as a template and then amplified using enzymes and materials similar to PCR reactions, but with the addition of certain reagents. This process is called cycle sequencing.

While the analysis of sequencing result, Blast can be used to identify a questionable nucleotide sequence (query sequence) that we have with the nucleotide database so that the output obtained is in the form of the identity of the nucleotide, including the 


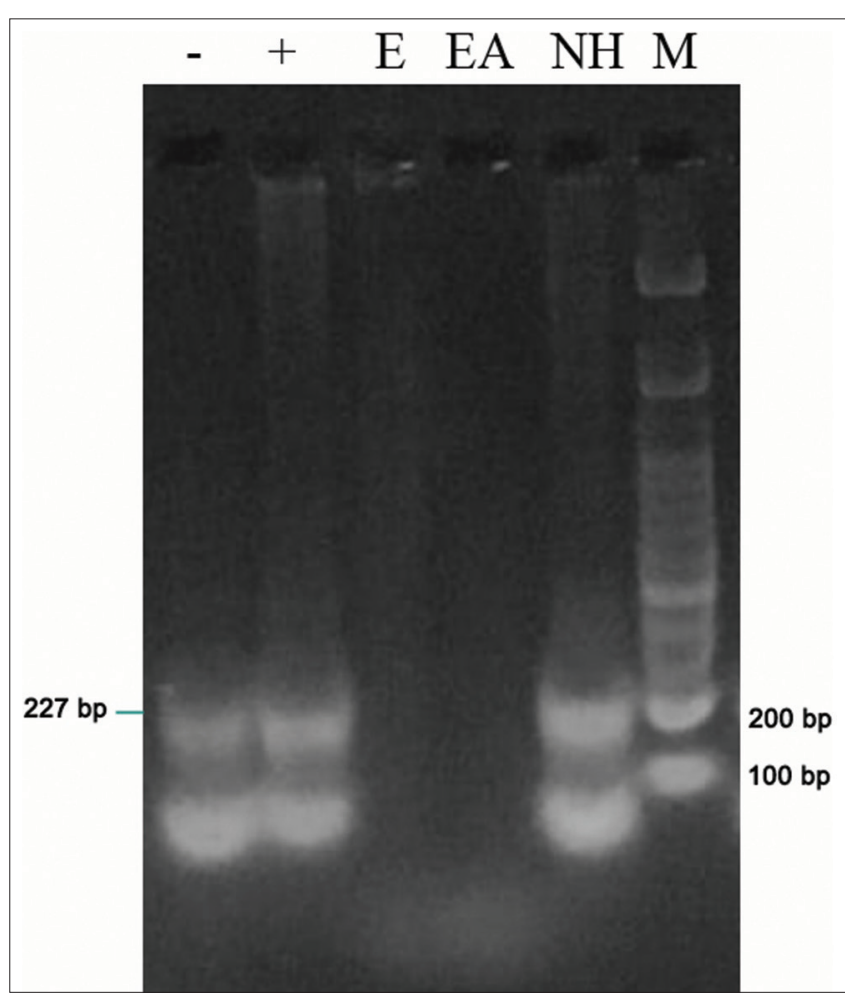

Figure 1: The result of $\beta$-catenin gene amplification using the PCR method, (Source: Personal Documentation, 2021). Desc: $-=$ Negative, $+=($ Positive $), E=(E t O H), E A=($ Ethyl acetate $)$, $N H=(n-h e x a n e)$, and $M=($ Marker $)$

name of the gene and the producing species of the complete sequence.

\section{Results}

This study investigated the effect of the EtOH extract, ethyl acetate fraction, and $\mathrm{N}$-hexane fraction of pokea extract on $\beta$-catenin gene mutation in mice using the PCR method and RFLP analysis (restriction digestion). The result of the $\beta$-catenin gene examination using the PCR method and the result of the $\beta$-catenin gene examination using the RFLP analysis (restriction digestion) can be seen below:

\section{Result of the examination of $\beta$-catenin gene using the PCR method}

The result of $\beta$-catenin gene amplification using the PCR method is presented in Figure 1.

Figure 1 shows that $\beta$-catenin gene amplification using the PCR method in the positive control, negative, and n-hexane obtains the same base pair, namely, $191 \mathrm{bp}$ and $82 \mathrm{bp}$. Meanwhile, EtOH and ethyl acetate treatments obtain the same result, namely, $56 \mathrm{bp}$. In this treatment, the total migration rate was $440 \mathrm{bp}$. The target band in this result was, if it was amplified, the band with a size of 227 bp was formed [8].

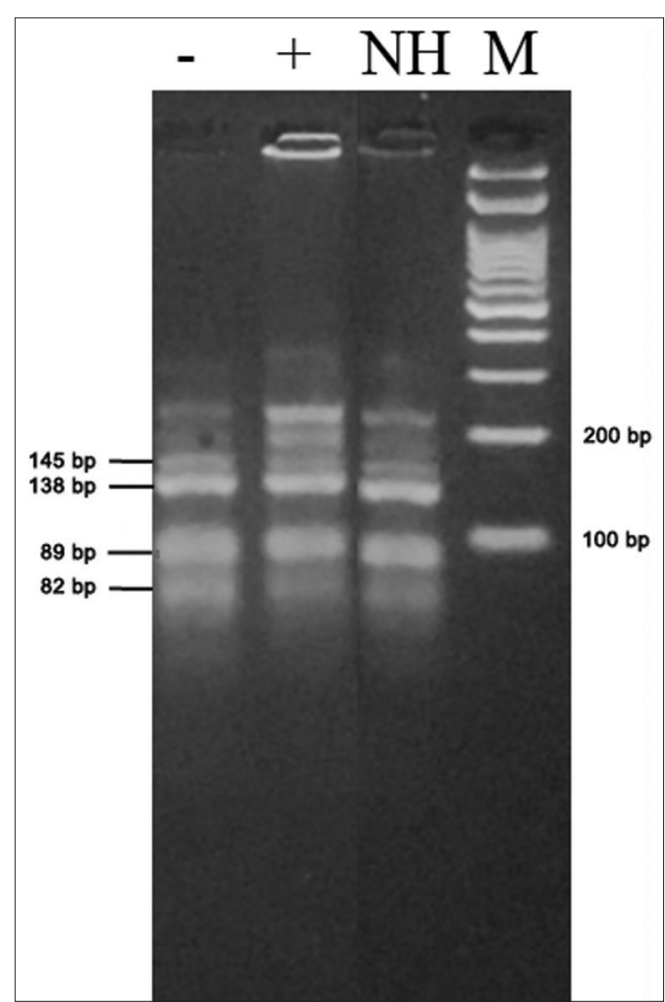

Figure 2: The result of $\beta$-catenin gene amplification using the RFLP analysis (restriction digestion). Desc: $-=$ Negative, $+=$ (Positive), $N H=(n-H e x a n e)$, and $M=(M a r k e r)$

Result of the examination of $\beta$-catenin gene using the RFLP analysis (restriction digestion)

The result of $\beta$-catenin gene amplification using the RFLP analysis (restriction digestion) is presented in Figure 2.

Based on Figure 2, to determine the sizes of the bands formed from the amplification of the $\beta$-catenin gene with RFLP Digestion, a standard curve of the $\beta$-catenin gene DNA was calculated based on the DNA marker size, migration rate, and total migration rate, from the PCR yield curve. DNA standard obtained the equation $y=-2.4932 x+3.4276$; with a value of $\mathrm{R}^{2}=0.9587$, the formula is used to calculate the length of the sample DNA so that the length of the DNA sample in each well is obtained as follows: The negative control obtained 48 bp, 70 bp, 155 bp, 180 bp, 249 bp, and $362 \mathrm{bp}$. The positive control obtained $53 \mathrm{bp}, 69 \mathrm{bp}$, $127 \mathrm{bp}, 151 \mathrm{bp}, 191 \mathrm{bp}, 234 \mathrm{bp}$, and $394 \mathrm{bp}$ and in the n-hexane treatment obtained $48 \mathrm{bp}, 69 \mathrm{bp}, 116 \mathrm{bp}$, $151 \mathrm{bp}, 180 \mathrm{bp}$, and $234 \mathrm{bp}$.

In this treatment, the total migration rate was $660 \mathrm{bp}$. The band with the objective criteria of the RFLP analysis (restriction digestion) in this study was, first, if the bands were $82.7 \mathrm{bp}$ and $138 \mathrm{bp}$, it indicated no $\beta$-catenin gene mutation (wild type). Second, if the bands were $89 \mathrm{bp}$ and $138 \mathrm{bp}$, the mutation happened in the first or second base at codon positions 32 or 33. Finally, if the bands were $82 \mathrm{bp}$ and $145 \mathrm{bp}$, the 
Table 1: Consensus and refseq alignment results (NM.001165902.1)

\begin{tabular}{lc}
\hline Consensus & TTT GCT GAC CTG ATG GAG TTG GAC ATG GCC \\
P3 & ATG GAG CCG GAC AGA AAA GCT GCT GTC AGC \\
CAC TGG CAG CAG CAG TCT TAC TTG GAT TCT \\
GTGCA ATC CAT TCT GGT GCC ACC ACC ACA GCT \\
CCT TCC CTG AGT GGC AAG GGC AAC CCT GAG \\
GAA GAA GAT GTT GAC ACC TCC CAA GTC CTT \\
TAT GAA TGG GAG CAA GGC TTT TCC CAG TCC \\
TTC ACG CAA GAG CAA GTA GCA AA \\
\hline Refseq & CGT CAG TGC AGG AGG CCG AGG CCG AGC \\
$\mathbf{2 . 1}$ & GGG CGG CCG CGA GGT ACC TGA AGC TCA \\
GCG CAC & 6116590 \\
GGC TGC TGT GAC ACC GCT GCG TGG ACA ATG \\
121 ATG GCC ATG GAG CCG GAC AGA AAA GCT \\
GCT GTC AGC CAC TGG CAG CAG CAG TCT \\
TAC TTG \\
181 GAT TCT GGAATC CAT TCT GGT GCC ACC ACC \\
ACA GCT CCT TCC CTG AGT GGC AAG GGC \\
AAC \\
241 CCT GAG GAA GAA GAT GTT GAC ACC TCC \\
CAA GTC CTT TAT GAA TGG GAG CAA GGC TTT \\
TCC \\
301CAG TCC TTCACG CAA GAG CAA GTA GCT GAT \\
ATT GAC GGG CAG TAT GCA ATG ACT AGG \\
GCT
\end{tabular}

mutation happened in the second or third base at codon positions 34 and 35 [1].

The result of identifying the bad size obtained in Figures 1 and 2 in the n-hexane fraction was continued by conducting the sequencing test to know the gene types that were considered experiencing the repair mechanism of mutation.

Table 2: Result of the BLAST for $\beta$-catenin gene in the $n$-hexane fraction

\begin{tabular}{|c|c|c|c|}
\hline No. & Name of species & $\begin{array}{l}\text { Homological } \\
\text { percentage }\end{array}$ & Accession \\
\hline 1. & $\begin{array}{l}\text { Mus musculus targeted KO-first, } \\
\text { conditional ready, lacZ-tagged mutant allele } \\
\text { Ctnnb1:tm1a(EUCOMM)Hmgu; transgenic }\end{array}$ & 99.13 & JN956086.1 \\
\hline 2. & $\begin{array}{l}\text { Mus musculus targeted non-conditional, lacZ- } \\
\text { tagged mutant allele Ctnnb1:tm1e(EUCOMM) } \\
\text { Hmgu; transgenic }\end{array}$ & 99.13 & JN952341.1 \\
\hline 3. & $\begin{array}{l}\text { Mus musculus catenin (cadherin-associated } \\
\text { protein), beta } 1 \text { (Ctnnb1), transcript variant } 2 \text {, } \\
\text { mRNA }\end{array}$ & 99.13 & NM_001165592.1 \\
\hline 4. & $\begin{array}{l}\text { Mus musculus catenin (cadherin-associated } \\
\text { protein), beta } 1 \text { (Ctnnb1), transcript variant } 1 \text {, } \\
\text { mRNA }\end{array}$ & 99.13 & NM_007614.3 \\
\hline
\end{tabular}

The sequencing results in the form of a chromatogram, shown in Figure 3, were then edited using the BioEdit program to remove unnecessary bases and combine the two sequence results from the forward and reverse primers, namely, contig analysis. The nucleotide arrangement of the isolates obtained from the results of the contig analysis was then identified by comparing the sample DNA sequences with the $\beta$-catenin gene reference (NM.001165902.1), shown in Table 1, at the National Center for Biotechnology Information in the BioEdit software to see changes in the sequence that occurred. After the comparison, it can be seen that there has been a change in the GGA $\rightarrow$ GTGC sequence at codon 30 bases to 188 which is a transversion mutation where the base $\mathrm{G}$ becomes $\mathrm{T}$, and insertion is identified, namely, the addition of a nitrogen base, namely, base GC.

\section{Discussion}

Colorectal cancer is cancer leading to the malignant tumor in the colon (the longest part of the large intestine/colon) and the rectum (the longest part of the large intestine/colon before the anus). Gene mutation is a change occurred in the genetic materials in the cells. The material changes in colorectal cancer can cause characteristic changes, both at the cell level and in the living creatures. $\beta$-catenin gene mutation, APC will decrease the $\beta$-catenin improvement. The result of this depletion of the $\beta$-catenin gene will translocate the $\beta$-catenin gene in the nucleus; with this change, the genetic change will activate the mutation in an oncogene that will allow the neoplastic transformation into cancer [2].

PCR-RFLP is one of the DNA characterizations based on the different cutting sites. The cutting was done by an endonuclease restriction enzyme that can digest DNA and cut the DNA in a certain restriction site into fragments. The PCR-RFLP utilization in this identification is knowing the effect of Poke extract treatment (n-hexane, EtOH, and ethyl acetate) in mice infected with pada AOM/DSS) [9].

One of the factors causing cancer is the result of mutations in chromosomal DNA of normal cells that can be triggered by external factors (tobacco, alcohol, chemical substances, infection agents, and radiation); meanwhile, the internal factors are hormone, immunity, congenital mutation, and mutation happened in the metabolism. It can be characterized by the clinical utilization in the pharmacology of drugs from marine organisms. The anticancer effect is marked by an evaluation of the apoptosis effect of clam extract, showing that it has an inhibitory effect in human cancer cell proliferation [10].

Figure 1 shows the result of the PCR in this study indicates the success in the $\beta$-catenin gene amplification in the positive control, negative, and n-hexane. It is characterized by the occurrence of a target band of $227 \mathrm{bp}$, while the $\mathrm{EtOH}$ and ethyl acetate treatments do not show any amplification with a size of $227 \mathrm{bp}$. It shows that the $\beta$-catenin gene is not formed. The occurrence of a band in the negative treatment was caused by the characteristic of $\beta$-catenin gene mutation in the normal DNA of animals and humans in the normal condition. Therefore, in the negative treatment, several bands nearly similar to those of positive control occur [11].

Figure 2 shows the PCR-RFLP analysis (restriction digestion) with the bands of $89 \mathrm{bp}$ and $138 \mathrm{bp}$, indicating that the mutation occurs in the first or second base at codon position 32 or 33; besides, the bands of $82 \mathrm{bp}$ and $145 \mathrm{bp}$ show a mutation in the second or third base at codon position 34 and 35 in the n-hexane fraction. It is also supported in the sequencing test in the $\mathrm{n}$-hexane showing the repair mechanism of mutation. 


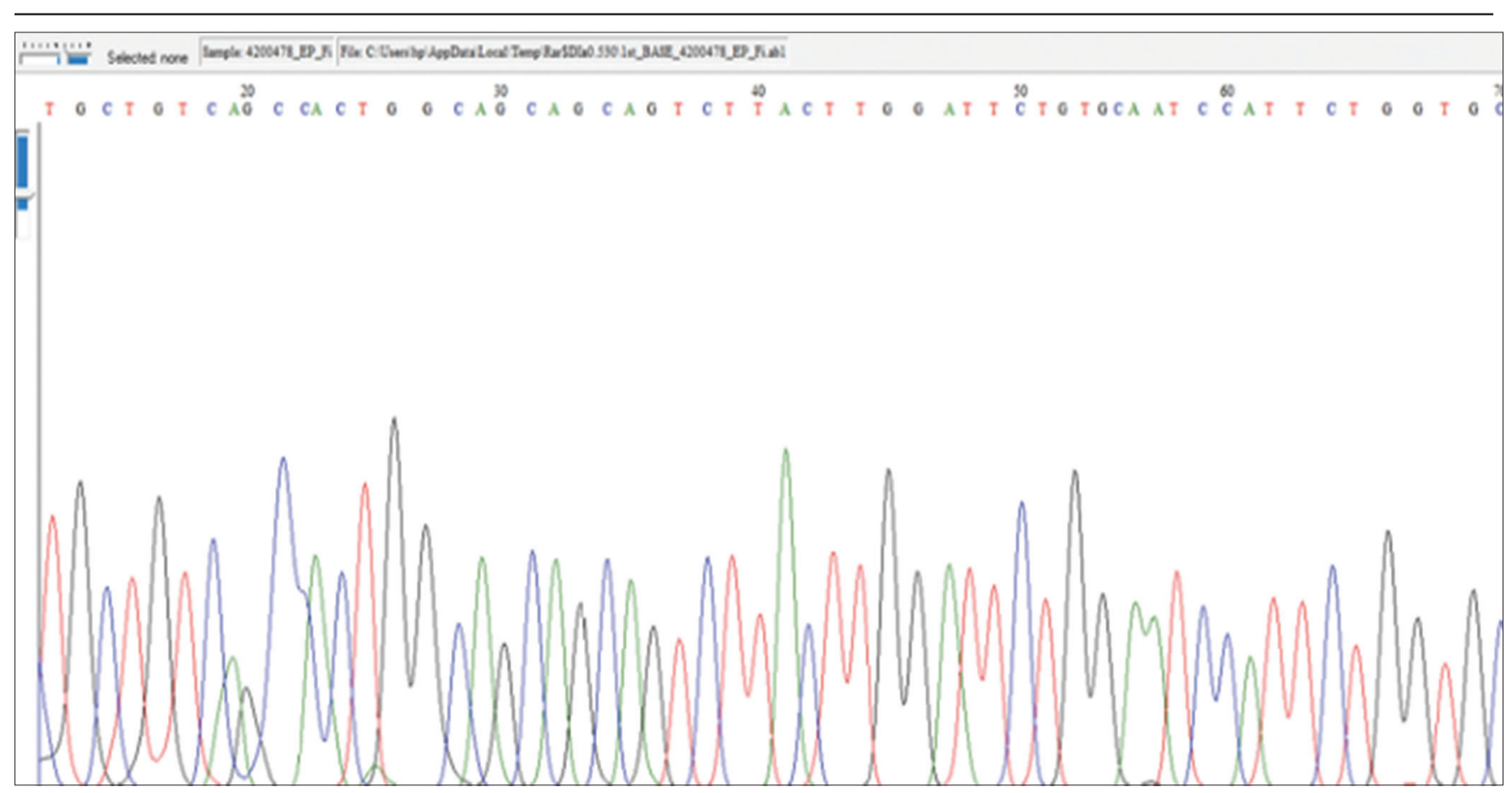

Figure 3: Sequencing results of mouse isolates after the treatment of Batissa violacea extract with $N$-hexane fraction as a solvent used

The occurrence of non-specific bands in this study is affected by the optimization of the annealing temperature of DNA in the PCR machine. The optimization of annealing temperature becomes the most important part of the amplification process. Too low and too high annealing temperatures make the primer unable to recombine on the specific place, improper primary annealing, the unstable optimal temperature during incubation with a constant temperature of $65^{\circ} \mathrm{C}$ for 20 min leading to primary annealing that does not fulfill the target, inaccurate process of pipetting or contamination when performing the work [12]. It is also revealed in the relevant study that the success of amplification is based on the suitability of primer and the efficiency and optimization of the PCR process [13].

Molecular identification in Table 2 shows that $n$-hexane obtains $99.13 \%$ of the $\beta$-catenin gene. The result of the $\beta$-catenin gene sequencing from the sample treated with $n$-hexane was traced its homology in the similar type of sample that existed in the GenBank through the BLAST program. If the homological presentation of a species is above $97 \%$, the species is denoted as the same species [14].

The $\beta$-catenin gene is frequently mutated at codons 33,41 , and 45 of the GSK-3 $\beta$ phosphorylation motif in human colon cancer. In addition, mutations often occur in rat colon tumors induced by AOM at codons 32 and 34. The second $G$ nitrogenous base of the CTGGA sequence is generally mutated to the nitrogenous base A in codons 32 and 34 of the mouse $\beta$-catenin gene and this pathway is considered a hotspot mutation with AOM (Takahashi et al., 1998). In the study of Mami et al. (2000), the mouse $\beta$-catenin gene was found to be mutated at codons $34,33,41$, and 37 , nine out of 10 mutations were $\mathrm{G}: \mathrm{C} \rightarrow \mathrm{A}: \mathrm{T}$ transition, but not at codon 32. Thus, the hotspot in codon 34 may be similar, further supporting the present study's hypothesis that the second $G$ of the CTGGA sequence is critical.

Based on the results obtained in this study, it can be assumed that the DNA of mice colon isolate samples that had been treated with pokea extract experienced changes in the beta-catenin gene sequence. Hence, it can be concluded that the treatment of pokea extract in the colon of mice has not been able to fully improve the mutations that occur in the $\beta$-catenin gene sequence. Mutations occurring in the $\beta$-catenin gene in $\mathrm{AOM}$-induced colorectal cancer of mice suggest that the consequent changes in protein stability and localization may play an important role in this model of colon carcinogenesis.

The current laboratory examination applies the molecular diagnostic-based method more since it is considered more sensitive, time saving, and the result is more optimal than the conventional method. One of the ways in performing the treatment using the molecular technique is collection the new and safe raw material of drugs from food materials using bioactive components from mollusks.

\section{Conclusion}

Based on the result of the study on using $\mathrm{EtOH}$ extract, ethyl acetate fraction, and $n$-hexane fraction for testing the effect of $\beta$-catenin gene mutation in mice induced by AOM and DSS, it shows that only the n-hexane fraction of pokea clam displaying the bands relevant to the target, namely, in the PCR process and 
restriction digestion with Hinfl. The result is reinforced by the identification using the sequencing method by obtaining the homological presentation of $\beta$-catenin of $99.13 \%$.

\section{References}

1. Mami T, Seiichi N, Takashi S, Keiji W. Frequent mutations of the $\beta$-catenin gene in mouse colon tumors induced by azoxymethane. Carcinogenesis. 2000;21(6):1117-20.

PMID: 10836998.

2. Morin PJ, Sparks AB, Korinek $V$, Barker $N$, Clevers $H$, Vogelstein $B$, et al. Activation of $\beta$-catenin-tcfsignaling in colon cancer by mutations in $\beta$-catenion. APC. Science (Washington DC) $1997 ; 275: 1787-90$.

3. Ahmad A, Hahn-Stromberg V. Expression of $\beta$-catenin and E-cadherin, their clinical significance and association with complexity index of colon carcinoma. Adv Genet Eng 2016;5(3):3. http://doi.org/10.4172/2169-0111.1000156

4. Winarsi H. Natural antioxidants and free radicals. Yogyakarta: Kanisius. 2007:23-88.

5. Rasyid SA, Bintang M, Priosoeryanto BP, Nurlila RU, Surya RA. Analysis chemical compound of pokea (Batissa violacea celebensis martens 1897) the origin of konawe regency SoutheastSulawesi. IndianJPublicHealthResDev.2018;9(6):345. https://doi.org/10.5958/0976-5506.2018.00576.4.

6. Sarker SD, Latif Z, Gray A. Natural Product Isolation. In: Methods in Biotechnology. 2nd ed. New Jersey: Human Press;
1996. p. 372-5

7. Jagveer S, Nalini K, Gary K, Bandaru SR. Modulation of azoxymethane-induced mutational activation of ras protooncogenes by chemopreventive agents in colon carcinogenesis. Carcinogenesis. 1994;5(17):1317-23. http://doi. org/10.1093/carcin/15.7.1317

PMid:8033306

8. Takahashi M, Kazunori F, Takashi S, Keiji W. $\beta$-Catenin is frequently mutated and demonstrates altered cellular location in azoxymethane-induced rat colon tumors. Cancer Res 1998;58:42-6.

9. Santoso S. Biologi. Jakarta: Interplus; 2007.

10. Kuroda K. UlasanInterdisipliner: Nanomedicine dan Nanobiotechnology. Vol. 5. Hoboken, New Jersey: Wiley; 2012 http://doi.org/10.1002/wnan.1199

11. Firestein RB, Bass AJ, Kim SY, Dunn IF, Silver SJ, Guney I, et al. CDK8 is A colorectal cancer oncogene that regulates B-catenin activity. Nature 2008;455(7212):547-51. http://doi.org/10.1038/ nature07179

PMid:18794900

12. Marchesi JR, Sato T, Weightman AJ, Martin TA, Fry JC, Hiom SJ, et al. Design and evaluation of useful bacterium-specific PCR primers that amplify genes coding for bacterial 16S rRNA Appl Environ Microbiol. 1998;64:795-9.

13. Adhiyanto $C$, Yamashiro $Y$, Hattori $Y$, Nitta T, Hino M, Matar M, et al. A new $\beta 0$-thalassemia mutation (codon 102, AAC>ATCAC) in coexistence with a heterozygousP4.2 nippon gene. Hemoglobin. 2013;37(3):227-40. http://doi.org/10.3109/036302 69.2013.777847

14. Baxevanis AD, Oullete BF. Bioinformatics of Practical Guide the Analysis of Genes and Proteins. 2nd ed. New York: John Willey and Sons Inc.; 2001. 